\title{
Kinetics of crystallization and melting of hydrate-paraffins and prediction of their formation in oil wells of Nepa-Botuobian anteclise (Eastern Siberia)
}

\author{
I. K. Ivanova ${ }^{1,2}$, V. V. Koryakina ${ }^{2}$, M. E. Semenov ${ }^{2}$, and I. I. Rozhin ${ }^{2}$ \\ Received 1 August 2017; revised 11 December 2017; accepted 13 December 2017; published 25 December 2017.
}

The study is focused on the results of kinetic analysis of processes of crystallization and melting of hydrates synthesized in model systems "natural gas + water" and "natural gas + asphaltene-resin-paraffin deposits (ARPD) + water". Synthesis and decomposition of hydrates in the systems under investigation were carried out in a calorimetric cell of differential scanning calorimetry (DSC). The kinetics description of processes is carried out applying the Avrami equation. Based on the obtained data, the rate constants, order of reactions, and half-life time periods of formation in gas and oil wells has shown that $P$, $T$-conditions hydrate-paraffin formation correspond to the actual thermobaric conditions of several oil and gas fields located in the permafrost area. KEYWORDS: Gas and hydrate systems; Biogeochemical kinetics; reaction modeling; Clathrate.

Citation: Ivanova, I. K., V. V. Koryakina, M. E. Semenov, and I. I. Rozhin (2017), Kinetics of crystallization and melting of hydrate-paraffins and prediction of their formation in oil wells of Nepa-Botuobian anteclise (Eastern Siberia), Russ. J. Earth. Sci., 17, ES5002, doi:10.2205/2017ES000611.

\section{Introduction}

Hydrates of hydrocarbon gases are solid compounds, formed under certain $P, T$-conditions from water and lowmolecular-weight gases [Byk et al., 1980] Makogon, 1985]. The higher the molecular mass of gas or a mixture of gases is, the lower is the pressure required for hydrate formation at a constant temperature. The mechanism of hydrate formation includes two stages: the formation of embryos and the sorption growth of crystallites of the hydrate around the embryos. Hydrate formation takes place at the "gas-water" interface. The rate of embryos formation of the hydrate crystallization depends on the magnitude of the external pressure and the degree of super-cooling of the process. The thermodynamic stability region of hydrates also covers positive temperatures. At moderate pressures, natural gas hydrates can occur up to $+20-25^{\circ} \mathrm{C}$.

Formation of hydrates of associated gases in oil wells is an acute problem for deposit development in the Russian Far North, as well as in Western and Eastern Siberia [Blanc and

\footnotetext{
${ }^{1}$ Federal State Autonomous Educational Institution for Higher Education, M. K. Ammosov North-Eastern Federal University, Yakutsk, Russia

${ }^{2}$ Federal State Budgetary Institution of Science, Institute of Oil and Gas Problems, Siberian Branch, Russian Academy of Sciences, Yakutsk, Russia
}

Copyright 2017 by the Geophysical Center RAS.

http://elpub.wdcb.ru/journals/rjes/doi/2017ES000611-res.html
Tournier-Lasserve, 1990 Elemanov and Gershtansky, 2007 Istomin, 1990, Sayakhov and Bagautdinov, 2003 Zalivin and Vakhromeyev, 2016. The well production is a multiphase mixture of associated gases, oil, and water (fresh or weakly mineralized), and oil and water in this case form water-inoil emulsions. At the corresponding pressures, low reservoir temperatures and the severe climate of these areas facilitate favorable conditions for hydrate formation in the forming water-in-oil emulsions, as a result the hydraulic resistance increases in wells, field, and major oil pipelines, while their throughput capacity is reduced due to clogging with hydrate plugs [Akhfash et al., 2016 Davies et al., 2009. Koh et al., 2012 Sloan, 2000 2011 Sloan and Koh, 2008 Turner et al., 2009 . Besides, the hydrate formation occurs during condensation of water vapor on paraffin deposits in the form of a drop or film [Elemanov and Gershtansky, 2007] Sayakhov and Bagautdinov, 2003 which results information of complex deposits, i.e. hydrate-paraffins.

A lot of works have been devoted to research the processes of hydrate formation in water-in-oil emulsions [Dalmazzone et al., 2006 2009. Delgado-Linares et al., 2013. Greaves et al., 2008 Gupta et al., 2008 Semenov et al.,2015 Stoporev et al., 2014. In works [Talatori and Barth, 2012. Talatori et al., 2008 special attention is paid to kinetics of hydrate formation in these systems as the knowledge of details of hydrate formation processes, accumulation and decomposition is the key factor for elaboration of new technologies to prevent hazards resulting from hydrate formation. Thus, it was shown in [Talatori et al., 2008] that the Avrami model is suitable for describing kinetics of hydrate formation in 
water-in-oil emulsions. It has been found out that the rate of hydrate formation depends on the amount of water in emulsions [Talatori and Barth, 2012]: the rate of hydrate formation decreases with the increasing water content, and the kinetic parameters of hydrate formation in emulsions determined by this model can be used to assess risks of hydrate formation in oil pipelines. The analysis of previous works shows that issues of hydrate formation in paraffin deposits and water have not been adequately studied. In [Ivanova et al., 2015, temperatures and pressures of phase transitions of natural gas hydrates synthesized in paraffin type asphalteneresin-paraffin deposits (ARPD) and water are determined by high-pressure differential scanning calorimetry (DSC), and our study continues the previous research on formation of natural gas hydrates in various systems [Ivanova et al.,2014. 2015 .

Thus, here we present our first data on the mechanism and kinetics of hydrate formation in the system "paraffin deposits + water". The results obtained may serve as a basis for prediction of complex deposits formation and determination of correspondence between the permissible periods of their accumulation/removal, as well as the choice of methods for removing hydrate-paraffin plugs.

\section{Experimental Part}

ARPD samples were taken from the surface of the oil tubing in the Irelyakhskoye gas and oil field (GOF) (Sakha Republic of Yakutia), with the following composition: 59.6 mass.\% of hydrocarbon mixture; 20.0 mass. \% of paraffins, 4.1 mass. \% of asphaltenes, 12.6 mass. $\%$ of resins; 3.7 mass. $\%$ of mechanical impurities with $0.882 \mathrm{~g} / \mathrm{m}^{3}$ density. Emulsion samples were prepared by mechanical mixing of ARPD and distilled water in a mass ratio of $\mathrm{H}_{2} \mathrm{O} / \mathrm{ARPD} 20 / 80,40 / 60$, $60 / 40$ and $80 / 20$ without added synthetic surfactants using a household mixer with a free blade at a speed of 11,000 $\mathrm{rpm} / \mathrm{min}$ for 30 minutes. When mixing water and ARPD with a component ratio of $80 / 20$, the maximum saturation of ARPD with water was reached, and the actual component ratio in this sample was $60 / 40$, therefore sample $80 / 20$ was excluded from the study [Ivanova et al., 2015.

Natural gas of the Srednevilyuiskoe gas condensate field (GCF) (Sakha Republic of Yakutia) was used as model of gas-hydrate-forming agent; its composition is given in Table 1 The choice of this gas as a model is determined by the similarity of its composition to that of reservoir gases of the Irelyakhskoye GOF [Kalacheva L. P. and Fedorova A. F., Baza dannykh "Sostav gidratov prirodnykh gazov mestorozhdeniy Leno-Tungusskoy neftegazonosnoy provintsii." Svidetelstvo o gos. registratsii bazy dannykh \# 2017620891 ot 11.08.2017 po zayavke \# 2017620612 ot 21.06.2017 (in Russian); Kashircev, 2003.

Hydrates of this gas synthesized in ARPD emulsions were selected as objects of this study. Their phase transitions were studied in a calorimetric cell of the high-pressure differential scanning calorimetry DSC 204 HP Phoenix (HP DSC, Netzsch, Germany). The relative error in the enthalpy measurements is $\pm 3 \%$, and the error in the temperature measure-
Table 1. Componential composition of natural gas (Srednevilyuiskoe GCF)

\begin{tabular}{lc}
\hline Component & Content, vol.\% \\
\hline $\mathrm{CH}_{4}$ & 92.70 \\
$\mathrm{C}_{2} \mathrm{H}_{6}$ & 5.24 \\
$\mathrm{C}_{3} \mathrm{H}_{8}$ & 1.21 \\
$i-\mathrm{C}_{4} \mathrm{H}_{10}$ & 0.10 \\
$n-\mathrm{C}_{4} \mathrm{H}_{10}$ & 0.12 \\
$\mathrm{~N}_{2}$ & 0.58 \\
$\mathrm{CO}_{2}$ & 0.05 \\
\hline
\end{tabular}

ments makes $\pm 0.1^{\circ} \mathrm{C}$. Steel crucibles closed with perforated aluminum caps were used in the experiments. The weight of the ARPD emulsion loaded into the crucible is approximately $35 \mathrm{mg}$. The discharge pressure in the cell was $50 \mathrm{bar}$, and it was dynamically maintained up to $+6^{\circ} \mathrm{C}$, then was switched to a stationary mode. The shooting mode of thermograms consisted of two segments: cooling to $-12 \div-22^{\circ} \mathrm{C}$ with a rate of temperature decrease of $0.1^{\circ} \mathrm{C} / \mathrm{min}$ with the obtained crystallization peak of hydrate-containing phase consisting of ice and hydrates; and heating to $+20^{\circ} \mathrm{C}$ with a rate of a temperature increase of $0.2^{\circ} \mathrm{C} / \mathrm{min}$ with obtained ice and hydrate melting peaks. For each of the samples under study, no less than two thermograms were obtained within the coordinates "signal $[\mathrm{mW} / \mathrm{mg}]$ - time (temperature) [min, $\left.\left({ }^{\circ} \mathrm{C}\right)\right] "$ [Ivanova et al., 2015].

Experimental curves of the conversion degree of water into the hydrate-containing phase $(\alpha)$ and hydrate decomposition $(\beta)$ are obtained in the coordinates $(\alpha$ or $\beta-t$, min) in the automatic mode according to the procedure given in the original software of the DSC. This method is based on the following relations (1) and (2):

$$
\begin{aligned}
\alpha(t)= & \frac{\int_{t_{0}}^{t}\left(d Q_{\text {cryst }} / d t\right) d t}{\int_{t_{0}}^{\infty}\left(d Q_{\text {cryst }} / d t\right) d t} \times 100 \% \\
\beta(t)= & \frac{\int_{t_{0}}^{t}\left(d Q_{\text {melt }} / d t\right) d t}{\int_{t_{0}}^{t_{\infty}}\left(d Q_{\text {melt }} / d t\right) d t} \times 100 \%
\end{aligned}
$$

where $\alpha(t)$ - the quantity of a hydrate-containing phase formed by the time $t$ in the crystallization process; $\beta(t)-$ the quantity of the hydrate decomposed by the time $t$ in the melting process; $Q_{\text {cryst }}$ - the amount of heat released by the time $t$ during the crystallization; $Q_{\text {melt }}$ - the amount of heat absorbed by the time $t$ during melting; $t_{0}$ - the commence of crystallization/melting; $t_{\infty}$ - the total crystallization/melting time.

The obtained curves of the conversion degree of the water contained in emulsions into hydrate, and the curves of the degree of hydrate decomposition were analyzed based on the Avrami equation (3) [Avrami, 1939] for topochemical reactions: 


$$
-\ln \left(1-\frac{q}{100}\right)=k t^{n}
$$

where $q$ - the degree of crystallization (ice + hydrate) $(\alpha)$ at cooling or the degree of hydrate decomposition $(\beta)$ at heating; $n$ - the constant that determines the nature of the crystallization/decomposition process $(n<1$ is the diffusion process; $n>1$ is the kinetic process, $n=1$ is the first order reaction, where the rate of chemical interaction is comparable with the rate of diffusion); $k$ - the constant that determines the rate constant of crystallization/decomposition; $t-$ the time, min.

The rate constants of crystallization/decomposition $\left(\mathrm{min}^{-1}\right)$ were calculated using the Sakovich equation (4) [Rozovskiy, 1974:

$$
K=n k^{1 / n}
$$

On the basis of the enthalpy of ice melting, the quantitative composition of hydrates in paraffin deposit emulsions was calculated according to the following relations (5):

$$
\alpha(\text { hydrate })=100 \%-\frac{\Delta H_{\text {ice }}}{334 C_{\text {water }}} \times 100 \%
$$

where $\alpha$ (hydrate) - the hydrate content, wt.\%, $\Delta H_{\text {ice }}-$ the specific heat of ice melting, $\mathrm{J} / \mathrm{g}, 334$ - the melting enthalpy of ice, $\mathrm{J} / \mathrm{g}, C_{\text {water }}$ - the water cut in the sample.

\section{Results and Discussion}

Figure 1 shows curves of the degree of phase transformations:a curve of crystallization of water droplets in the composition of emulsions into the hydrate-containing phase at cooling, a curve of a hydrate decomposition at heating.

Data on crystallization and melting of hydrates synthesized in distilled water are given in this figure for comparison. The kinetic curves of crystallization of hydrate - containing phases of ARPD emulsion samples are evident to be S-shaped (Figure 1 ), while the curves differ among themselves in duration of the induction period. The crystallization of a hydrate-containing phase in distilled water can formally be classified as a reaction with the maximal initial speed, since the acceleration period immediately follows the initial period on this curve, i.e. independent on the heterogeneous or homogeneous character of the system under study, the crystallization process starts immediately over the entire reaction surface or throughout the whole liquid phase volume. The acceleration period for all crystallization curves covers the range of transformation values from 10 to $70 \%$.

The hydrate decomposition curves of water and ARPD emulsions (Figure 1p) are also S-shaped, but in comparison with the crystallization curves, their induction periods are clearly pronounced due to the slow release of gas as a result of the melting of hydrates. Further, the acceleration period follows when mass hydrate melting and enhanced gas evolution occur within the range of the curve corresponding to the range of transformation values from 10 to $70 \%$. Periods of acceleration are known to be more informative on the ongoing process; therefore, this very section of the curves is more

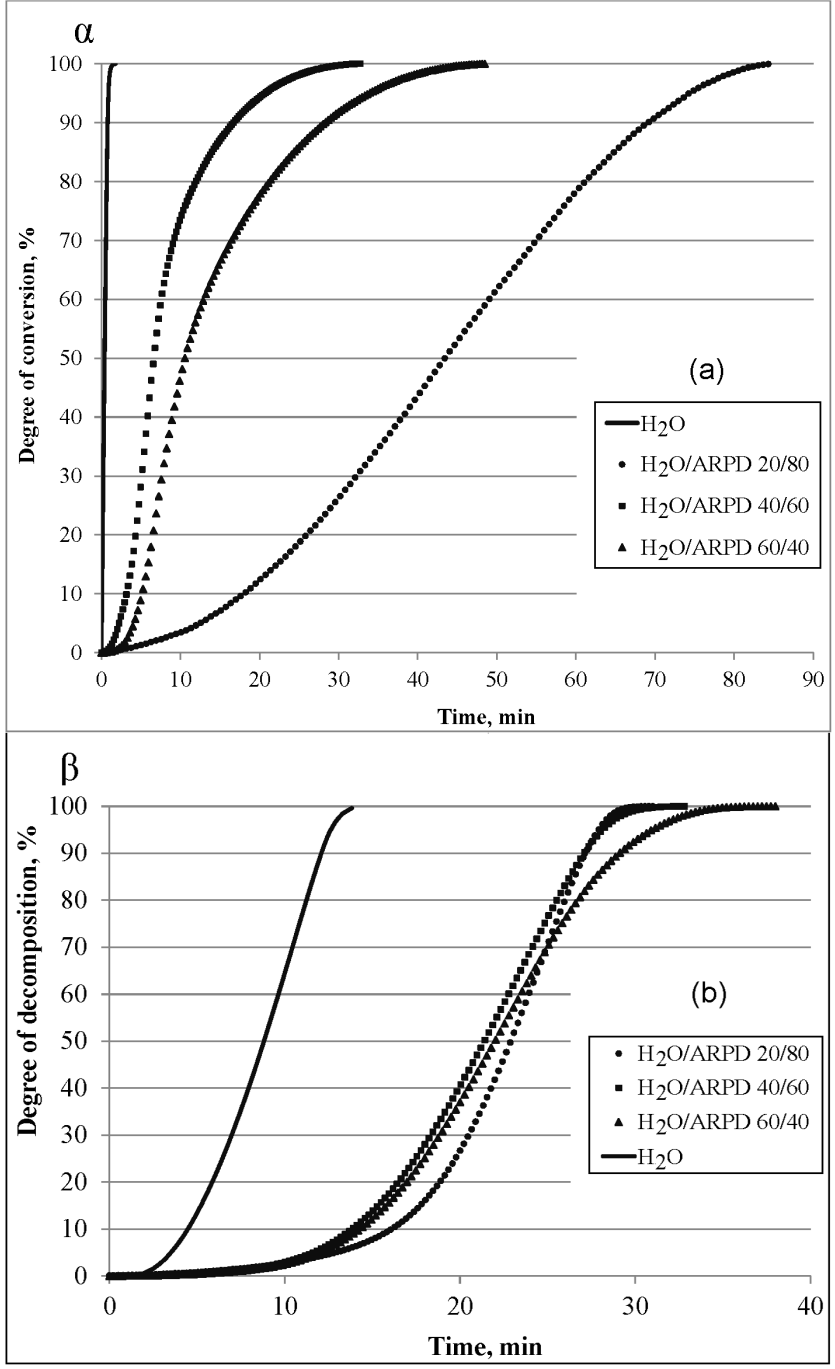

Figure 1. Kinetic curves of crystallization of hydratecontaining phases (a) and hydrate melting (b) synthesized in distilled water and in systems " $\mathrm{H}_{2} \mathrm{O} / \mathrm{ARPD}$ ".

interesting for kinetics analysis. Sections of decline periods on the kinetic curves are difficult to be analyzed and are of less value in terms of result interpretation, since these sections largely depend on individual characteristics of samples, making reproducibility of the curves impossible.

It is shown in [Kuo et al., 2006] that in a non-isothermal experiment, the Avrami equation can be applied to describe the crystallization/decomposition process at its initial stages, when the conversion degree is within the limits of $5-70 \%$. The logarithmic anamorphoses of the kinetic curves in the $q / 100$ coordinates (Figure 2 are obtained by logarithm of equation (3) for crystallization of hydratecontaining phases and hydrate decomposition in the composition of the investigated emulsions and distilled water. The validity of Avrami equation application to non-isothermal processes within the selected range is confirmed by straightening of logarithmic anamorphoses within these limits.

All logarithmic anamorphoses of crystallization processes 


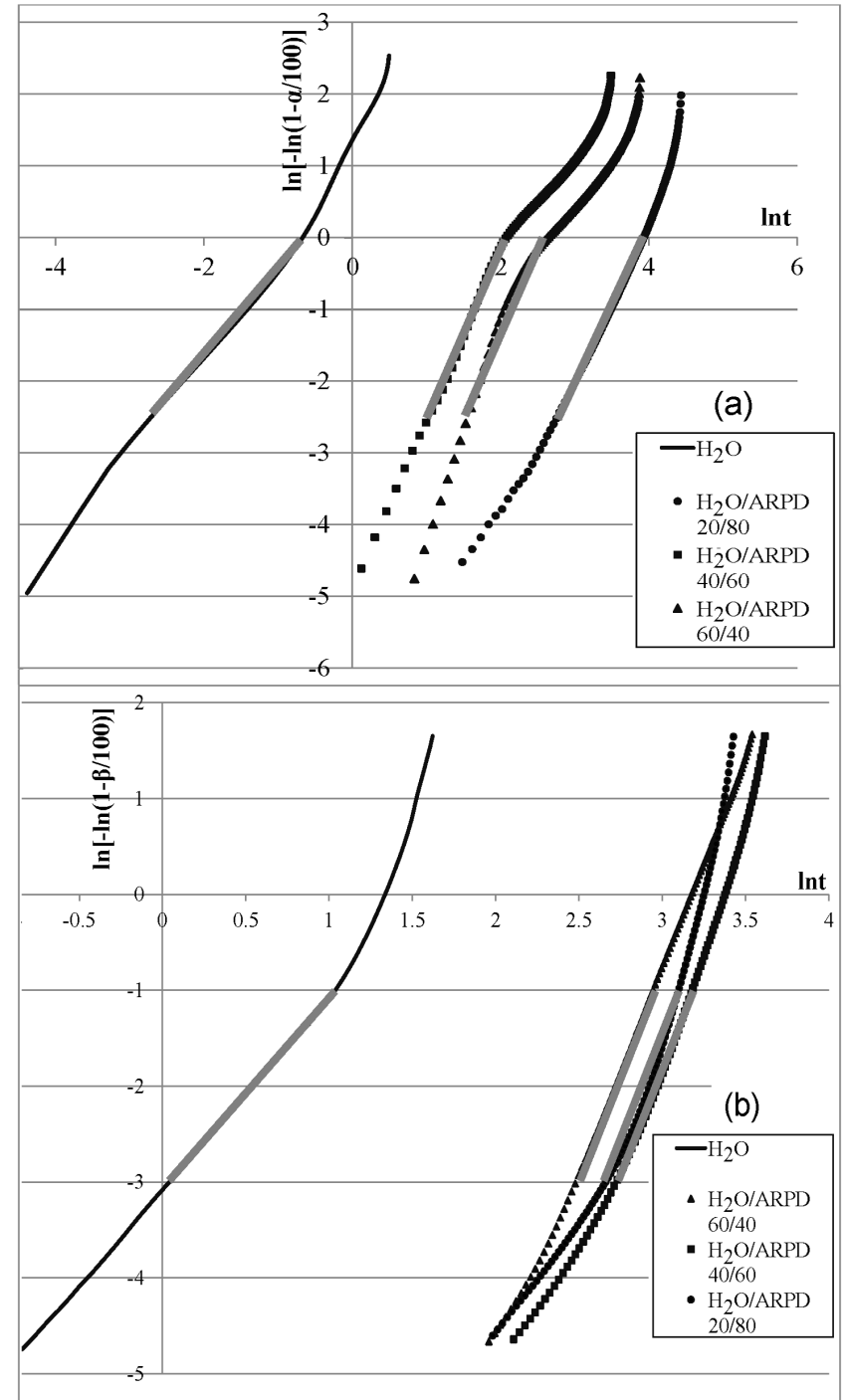

Figure 2. Logarithmic anamorphoses of kinetic curves of crystallization of hydrate-containing phases (a) and hydrate melting (b), synthesized in distilled water and " $\mathrm{H}_{2} \mathrm{O} /$ ARPD" systems. are straightened in the initial sections, where the degree of conversion makes $10-60 \%$. The anamorphoses of hydrate decomposition have straight sections at 5-30\% degrees of transformation. A narrower range as compared with crystallization may be due to a complicated mechanism of the hydrate phase melting process and to effects of heating rates.

The values of the Avrami equation parameter $n$, the approximation accuracy $\left(r^{2}\right)$, the half-life time periods $\tau_{0.5}$, and rate constant $K$ of crystallization/decomposition were calculated for the marked sections of anamorphoses of hydrate crystallization and melting processes (Table 2). Based on the obtained results, the quantitative content of ice and hydrate phases has been calculated in the emulsions and distilled water under study (Table 3 .

High values of approximation reliability (Table 2 demonstrate the validity of the equation choice for calculating the kinetic parameters within certain limits of $\alpha$. The parameter $n$ is defined as tangent of the inclination angle of the trend lines, and allows us to establish the reaction area. It is evident that, as compared with ARPD emulsions, crystallization of the hydrate-containing phase in bulk-distilled water proceeds an order of magnitude faster, the half-life time periods has minimal values, and the content of the hydrate phase makes only $3 \%$ (Table 3). The hydrate-containing phase in ARPD emulsions crystallizes by an order of magnitude slower, and the half-life time periods varies from 6.6 to $43.4 \mathrm{~min}$. The slow rate of crystallization could be determined by the high viscosity of emulsions [Stoporev et al., 2014, as well as by inhibitory effects of the asphaltenes included in the ARPD content in the hydrate formation process $[Z i$ et al., 2016]. Resulting from slow crystallization, the process proceeds with a high degree of water conversion into hydrate, and the hydrate content is in the range from 49 to $82 \%$. In this case it should be noted that when the mass fraction of water in the emulsion increases, the content of the hydrated phase in the samples decreases. The mechanism of crystallization of hydrate-containing phases in emulsions, regardless of the water cut, proceeds in the kinetic area $(n>1)$, i.e. the growth of the hydrate is directed towards the dispersed water droplets. The process of crystallization in distilled water occurs in the diffusion-kinetic

Table 2. Values of the Avrami equation parameter $n$, rate constants $K$, the half-life time periods $\tau_{0,5}$ for crystallization of hydrate-containing phases and decomposition of hydrate in distilled water and " $\mathrm{H}_{2} \mathrm{O} / \mathrm{ARPD}$ "

\begin{tabular}{|c|c|c|c|c|}
\hline Sample & $n$ & $r^{2}$ & $K, \min ^{-1}$ & $\tau_{0.5}($ graph $), \min$ \\
\hline \multicolumn{5}{|c|}{ Crystallization } \\
\hline " $\mathrm{H}_{2} \mathrm{O} / \mathrm{ARPD} " 20 / 80$ & 2.1 & 0.999 & 0.04 & 43.4 \\
\hline " $\mathrm{H}_{2} \mathrm{O} / \mathrm{ARPD} " 40 / 60$ & 2.5 & 0.996 & 0.32 & 6.6 \\
\hline " $\mathrm{H}_{2} \mathrm{O} / \mathrm{ARPD} " 60 / 40$ & 2.8 & 0.992 & 0.24 & 10.5 \\
\hline Distilled Water & 1.5 & 0.991 & 3.40 & 0.4 \\
\hline \multicolumn{5}{|c|}{ Decomposition } \\
\hline " $\mathrm{H}_{2} \mathrm{O} / \mathrm{ARPD} " 20 / 80$ & 4.6 & 0.998 & 0.16 & 22.5 \\
\hline " $\mathrm{H}_{2} \mathrm{O} / \mathrm{ARPD} " 40 / 60$ & 4.3 & 0.999 & 0.18 & 21.1 \\
\hline " $\mathrm{H}_{2} \mathrm{O} / \mathrm{ARPD} " 60 / 40$ & 4.3 & 0.999 & 0.18 & 22.0 \\
\hline Distilled Water & 2.0 & 0.992 & 0.46 & 3.4 \\
\hline
\end{tabular}




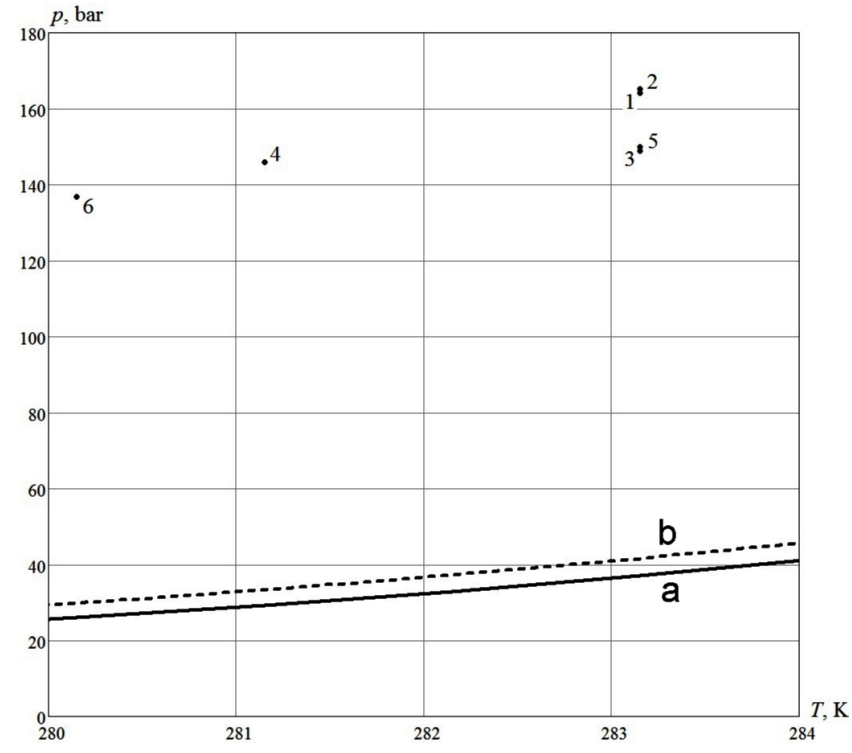

Figure 3. Equilibrium curve of hydrate formation of natural gas: a - calculated for distilled water; $\mathrm{b}$ - experimental for " $\mathrm{H}_{2} \mathrm{O} / \mathrm{ARPD}$ " systems. Points correspond to reservoir conditions of oil and gas fields: 1 - the Irelyakhskoe field, 2 - the Machobinskoe field, 3 - the Nelbinskoe field, 4 - the Taas-Yuryzkhskoe field, 5 - the Srednebotuobinskoe field, 6 - the Chayandinskoe field.

area $(n=1.5)$, i.e. the hydrate is formed on the contact surface of the "gas-water" phases.

The values of $n>1$ of hydrate decomposition indicate the complexity of this mechanism, and in cases of melting of hydrate-paraffins this index has the maximum values and lays in the range from 4.3 to 4.6 . The rate of decomposition of the hydrate synthesized in distilled water is two times higher, while its period of semi-decomposition is six times less compared with hydrate- paraffins which indicates the stability of the latter. The stability of hydrate-paraffins can be explained by their high sorption ability, due to which the hydrates in these systems are coated with a film of liquid and solid hydrocarbons such as: resins, asphaltenes and paraffins which strengthen the hydrates and make them more resistant to destruction.

Based on previously obtained experimental results [Ivanova et al., 2014] 2015], the calculated equilibrium curve for hydrate formation in distilled water and the experimental equilibrium curve for hydrate formation in the " $\mathrm{H}_{2} \mathrm{O} / \mathrm{ARPD}$ " systems have been constructed. These curves can be used to predict formation of hydrate-paraffins in oil wells of the Nepa-Botuobian anteclise (NBA). For this purpose, the points were plotted on the resulting graph Figure 3, which correspond to $P, T$-conditions at the bottom hole of wells of some gas-oil fields of the NBA [Kalacheva et al., 2015, whose reservoir gas composition is close to the composition of the used natural gas [Rozhin, 2015]. All the points are shown to lie above the equilibrium curve of hydrate formation. This implies that in oil production, hydrate paraffins-could be formed on equipment walls with the water content of the ARPD making $20-80 \%$ by weight resulting
Table 3. Average values of hydrate content in distilled water and " $\mathrm{H}_{2} \mathrm{O} / \mathrm{ARPD}$ " systems

\begin{tabular}{lc}
\hline Sample & $\alpha$ (hydrate), wt.\% \\
\hline "H $\mathrm{H}_{2} \mathrm{O} /$ ARPD" 20/80 & 82 \\
" $\mathrm{H}_{2} \mathrm{O}$ /ARPD" 40/60 & 78 \\
" $\mathrm{H}_{2} \mathrm{O}$ /ARPD" 60/40 & 49 \\
Distilled Water & 3 \\
\hline
\end{tabular}

to a production decrease and even to wellbore blockage. In the upper part of the well, due to thermal interactions with surrounding permafrost rocks, the oil temperature decreases thus leading to further intensification of hydrate-paraffin formation.

Currently, an issue of ARPD formation in oilfield equipment is acute for the Irelyakhskoe field. Gas condensate mined in the same field is used to remove deposits from the equipment. However, deposits cannot be completely removed, due to the low efficiency of gas condensate as an ARPD solvent [Ivanova and Shitz, 2009]. It should be borne in mind, that the presence of ARPD on the walls of oilfield equipment increases the risk of hydrate formation, as paraffin on the walls of the elevator pipes leads to local narrowing and an increase of the pressure drop, and, consequently, to an additional temperature decrease in the gas-liquid flow [Sayakhov and Bagautdinov, 2003]. As Figure 3 shows, selection of the non-hydrate mode for well operation is impossible for the given reservoir conditions. Therefore, usage of effective solvents for ARPD removal and selection of hydrate formation inhibitors are required first of all.

\section{Conclusion}

Research into kinetic features of crystallization and decomposition of hydrate-paraffins has been conducted and prediction of their formation in oil wells of Eastern Siberia has been made. It has been established that the crystallization rate of the hydrate-containing phase in bulk distilled water proceeds an order of magnitude faster than the crystallization of hydrate-paraffins. The degree of conversion of water into hydrate in ARPD emulsions is shown to depend on the water content and crystallization rate: the lower the rate constant and the amount of the aqueous phase in the emulsion are, the higher is the degree of conversion of water into hydrate. The growth of hydrates in dispersed water droplets of ARPD emulsions is directed towards the drops, whereas in bulk waters, hydrate formation occurs at the interface between the phases "water-gas". Analysis of the melting curves has shown that hydrate-paraffins are more resistant to decomposition, as compared with hydrates synthesized in distilled water. Prediction of hydrate-paraffin formation has shown that there is a risk of their occurrence in gas-oil wells of the Nepa-Botuobian anteclise. Therefore, to prevent formation of complex solid deposits consisting of ARPD and hydrates in operating oil deposits in the permafrost area, continuous monitoring of occurrence and re- 
moval of ARPD is required, since, stable hydrate-paraffins with the water content of ARPD from 20 to $80 \%$ by weight could be formed resulting in blockage of a wellbore and an emergency situation.

Acknowledgments. The authors are grateful to the reviewers for their discussion and valuable comments that contributed to the improvement of the submitted materials. The study has been financially supported by the Ministry of Education and Science of the Russian Federation in line with the base part of State Assignment (Project No. 1896 "Organization of Research Activities").

\section{References}

Akhfash, M., Z. M. Aman, S. Y. Ahn, M. L. Johns, E. F. May (2016), Gas hydrate plug formation in partially-dispersed water-oil systems, Chem. Eng. Sci., 140, 337-347.

Avrami, M. (1939), Kinetics of Phase Change, J. Chem. Phys., 7, $1103-1112$

Blanc, C., J. Tournier-Lasserve (1990), Controlling hydrates in high-pressure flowlines, World Oil, 211, No. 5, 63.

Byk, S.Sh., Yu. F. Makogon, V. I. Fomina (1980), Gazovyye Gidraty, Moscow, Khimiya. (in Russian)

Dalmazzone, D., N. Hamed, C. Dalmazzone (2009), DSC Measurements and modeling of the kinetics of methane hydrate formation in water-in-oil emulsion, Chem. Eng. Sci., 64, No. $9, \quad 2020-2026$.

Dalmazzone, D., N. Hamed, C. Dalmazzone, L. Rosseau (2006) Application of high pressure DSC to the kinetics of formation of methane hydrate in water-in-oil emulsion, J. Therm. Anal. Calorim., $85, \quad 361-368$.

Davies, S. R., et al. (2009), Predicting hydrate-plug formation in a subsea tieback, SPE Prod. Oper., 24, 573578.

Delgado-Linares, J. G., A. A. Majid Ahmad, E. D. Sloan, C. Koh, A. K. Sum (2013), Model water-in-oil emulsions for gas hydrate studies in oil continuous systems, Energy Fuels, 27, No. 8, 4564-4573.

Elemanov, B. D., O. S. Gershtansky (2007), Oslozhneniya Pri Dobyche Nefti, Nauka, Moscow. (in Russian)

Greaves, D., J. Boxall, J. Mulligan, E. D. Sloan, C. A. Koh (2008), Hydrate formation from high water content-crude oil emulsions, Chem. Eng. Sci., 63, 4570-4579.

Gupta, A., J. Lachance, E. D. Sloan, C. A. Koh (2008), Measurements of methane hydrate heat of dissociation using high pressure Differential Scanning Calorimetry, Chem. Eng. Sci., $63, \quad 5848-5853$.

Ivanova, I. K., M. E. Semenov, V. V. Koryakina, E. Yu. Shits, I. I. Rozhin (2015), Investigation of natural gas hydrates formation/decomposition processes in systems consisting of "commercial asphaltene-resin-paraffin deposits and water", Russian Journal of Applied Chemistry, 88, No. 6, 941-948.

Ivanova, I. K., E. Yu. Shitz (2009), Using of the gas condensate for fighting with organic deposits in the condition of abnormally low reservoir temperatures, Oil Industry, 12, 99-101.

Ivanova, I. K., M. E. Semenov, I. I. Rozhin (2014), Synthesis and phase transformations of natural gas hydrates of Srednevilyuiskoe field, Russian Journal of Applied Chemistry, 87, No. 8, 1094-1098.

Istomin, V. A. (1990), Preduprezhdeniye i Likvidatsiya Gazovykh Gidratov v Sistemakh Sbora i Promyslovoy Obrabotki Gaza i Nefti, Vsesoyuz. Nauch.-Issled. In-t Ekonomiki Gazovoy Promyshlennosti, Moscow. (in Russian)
Kalacheva, L. P., A. F. Fedorova, E. Y. Shitz, I. I. Rozhin (2015), Characteristic patterns in natural gas hydrate composition and structure in deposits of Yakutia, SOCAR Proceedings, 3, No. 3, 4-8.

Kashircev, V. A. (2003),

Organicheskaya Geokhimiya Naftidov Vostoka Sibirskoy Platformi, YaF Izd-vo SO RAN, Yakutsk. (in Russian)

Koh, C. A., A. K. Sum, E. D. Sloan (2012), State of the art: Natural gas hydrates as a natural resource, Journal of Natural Gas Science and Engineering, 8, 132-138.

Kuo, M. C., J. C. Huang, M. Chen (2006), Non-isothermal crystallization kinetic behavior of alumina nanoparticle filled poly(ether ether ketone), Materials Chemistry and Physics, 99, No. 2-3, 258-268.

Makogon, Yu. F. (1985), Gazovyye Gidraty, Preduprezhdeniye Ikh Obrazovaniya i Ispol'zovaniya, Nedra, Moscow. (in Russian)

Rozovskiy, A. Ya. (1974), Kinetika Topokhimicheskikh Reaktsiy, Khimiya, Moscow. (in Russian)

Rozhin, I. I. (2015), Termodinamicheskiye effekty v matematicheskikh modelyakh dobychi prirodnogo gaza $\mathrm{v}$ severnykh regionakh, Doctoral thesis, IT SO RAN, Novosibirsk. (in Russian)

Sayakhov, F. L., N. Ya. Bagautdinov (2003), Electrothermal Methods of Action on Hydrate-Paraffin Sediments, NedraBusiness, Moscow. (in Russian)

Semenov, M. E., et al. (2015), DSC and thermal imaging studies of methane hydrate formation and dissociation in water emulsions in crude oils, J. Therm. Anal. Calorim., 119, No. $1, \quad 757-767$.

Sloan, E. D. (2000), Hydrate Engineering (Ed. by J. B. Bloys), Richardson, Texas.

Sloan, E. D. (2011), Natural Gas Hydrates in Flow Assurance, Elsevier, GPP.

Sloan, E. D., C. A. Koh (2008), Clathrate Hydrates of Natural Gases, 3rd edition, CRC Press, Boca Rator, London, New-York.

Stoporev, A. S., A. Y. Manakov, E. Y. Aladko, L. K. Altunina, A. V. Bogoslovskii, L. A. Strelets (2014), Dependence of the rate of formation and the $P-T$ stability field of methane hydrate suspensions in crude oils upon oil composition, Petroleum Chemistry, 54, No. 3, 171-177.

Talatori, S., T. Barth (2012), Rate of hydrate formation in crude oil/gas/water emulsions with different water cuts, Journal of Petroleum Science and Engineering, 80, 32-40.

Talatori, S., P. Fotland, T. Barth (2008), Kinetics of hydrate formation in a water-oil-gas system, Proc. 6-th Int. Conf. Gas Hydrates, Vancouver, Canada. (Kinetics_of_hydrate_formation_ in_a_water-oil_gas_system)

Turner, D., K. Miller, E. Sloan (2009), Methane hydrate formation and an inward growing shell model in water-in-oil dispersions, Chem. Eng. Sci., 64, 3996-4004.

Zalivin, V. G., A. G. Vakhromeyev (2016), Avariynyye Situatsii v Burenii, Izd-vo IRNITU, Irkutsk. (in Russian)

Zi, M., D. Chen, H. Ji, G. Wu (2016), Effects of asphaltenes on the formation and decomposition of methane hydrate: Amolecular dynamics study, Energy Fuels, 30, No. 7, $5643-5650$.

I. K. Ivanova, Federal State Autonomous Educational Institution for Higher Education, M. K. Ammosov North-Eastern Federal University, Belinskiy str., 58, Yakutsk, 677000, Russia. (iva-izabella@yandex.ru)

V. V. Koryakina, I. I. Rozhin, and M. E. Semenov, Federal State Budgetary Institution of Science, Institute of Oil and Gas Problems, Siberian Branch RAS, Oktyabrskaya str., 1, Yakutsk, 677980, Russia. 